\title{
New Periodicals of 1948-Part II
}

Miss Brown is head, serials section, Descriptive Cataloging Division, Library of Congress.

$\mathrm{T}$

HIS compilation of periodicals comprises those which came to the attention of the writer during the second half of 1948. They are included because of their reference value or their interest to the general reader. The majority of them had their origin outside the Unted States.

\section{Political Science}

A number of new journals, many of them foreign, are being published to present the problems of national governments and international relations and to aid in their solution. One of these is Asian Horizon. It is published in London. In it able Asiatic writers and scholars discuss the awakening in their countries. The content of the first issue is classified as follows: Asia and the West; History ; Politics; Contemporary Art. To appraise the world about Korea and her cultural ideals the Korean-American Cultural Association with international headquarters in Washington, is publishing the Korean Review. The contributors to the first issue are professors and students, many of them Korean, teaching and studying in American universities. Pakistan Horizon, published in Karachi, promises to cover all aspects of international affairs with emphasis on those in which the new dominion of Pakistan will be directly interested. Eastern Review, published in Klagenfurt, which has as subtitle "a survey of the cultural life of east central and south-eastern Europe and of the Soviet Union," and The New Central European
Observer, published in London, present the current political and economic and, to a lesser degree, the cultural life for the countries of central and south-eastern Europe. Broader in scope is World Politics, published by the Yale Institute of International Studies. This journal is devoted to the developments of international relations as an integrated field of study and is designed to interest professional students of world affairs. The contributors to the first issue were economics and political science professors. Etudes Internationales, with some contributions in English, French and Dutch, the last two with English summaries, aims to present an impartial study of international questions. It is published by Nederlandsch Genootschap voor Internationale Zaken with headquarters at The Hague and Institut des Relations Internationales with headquarters in Brussels. The purpose of Contemporary Issues, published in London, similar to that of Dinge der Zeit, a German emigré magazine also published in London, is the formation of an international democratic organization which "is not to appear as a finished organisation, but to arise under public control." Corps Diplomatique, published in Paris, intends to contribute to international understanding by reporting honestly on international political and cultural life, emphasizing the role of France in both of these.

\section{Economics}

Économie Wallonne, Liége, will present studies on national and international economic problems which have an influence on the economic problems of the region of the 
Walloons. The first issue treats of the economic situation in Belgium, Holland, France, Great Britian, western Germany and the United States. Revista de Economia, Lisbon, will be devoted to the theoretical problems of economics and will publish scientific reports, studies, book reviews and abstracts. China Economist, weekly economic supplement to the China Weekly Review, Shanghai, has for its field the present economic conditions of China.

\section{City Government}

From Stuttgart there comes a new publication on city government, Der Städtetag, which is limited almost entirely to articles on the practices and problems of the government of German cities.

\section{Business}

La Revue du Chef d'Entreprise, Paris, is a journal of business management, selling, prices, etc. World Trade Review, New York, is a paper for exporters and importers. It publishes U.S. and foreign government trade regulations and reports on items available for export and import, lists firms with their products, and includes statistics and other information of interest to foreign traders.

\section{Literature}

Asir, from Mercedes, Uruguay, and Contrapunto, from Caracas, Venezuela, with essays, poems, translations and bibliographical notes will give us some idea of present day writing and thinking in those countries. Lusitânia, Documentário da Vida Portuguesa, includes articles on literary subjects, the ballet, present day medicine, the Portuguese language and other subjects showing contemporary Portuguese thinking. From Stockholm come Poesi, Tidskrift för Lyrik, published by Lyriksamfundet, and Prisma. The second, a little broader in scope, in- cludes art. In The Swan of Avon, Santa Barbara, California, Rudolf Melander, of the Melander Shakespeare Society, proposes to further his Melander Shakespeare theory. Italian Publishers' Monthly, Milan, and Le Livre, Revue Générale de l'Édition, Paris, include biographical and critical articles as well as announcements which give bibliographical items and descriptive notes on the new publications in their respective countries. Quoting from an introduction to Neurotica, this journal is to be "a literary exposition, defense, and correlation of the problems and personalities that in our culture are defined as 'neurotic.' ... We are interested in exploring the creativeness of this man who has been forced to live underground, and yet lights an utter darkness with his music, poetry, painting, and writing."

\section{Little Magazines}

Two "little" magazines appeared. The Golden Goose, Columbus, Ohio, is primarily interested in the work of the new American poet. Translations of foreign language poetry as well as the work of established poets will be included. Factotum, Chapel Hill, N.C., will publish the works of new writers. The contributors to the first issue were students and teachers of languages.

\section{Religion}

Zeitschrift für Religions- und Geistesgeschichte, a new philosophical and religious journal, was received from Marburg. Included in the first issue were articles on new Hegel documents and the Russian church and western Christianity.

\section{Archaeology, Ethnology, Folklore}

Archaeology, a Magazine Dealing with the Antiquity of the $W$ orld, is published by the Archaeological Institute of America. 
In a popular style and with many illustrations the editor hopes to present the "good and amusing things of the past" in order that we "return to the present refreshed and broadened in experience." Archives Ethnos, published in Buenos Aires in Spanish and in English editions, abstracts ethnological articles, reports, and studies published in scientific journals of South America and Europe. The first issue contained ten such abstracts. North Carolina Folklore, a publication of the Folklore Council of the University of North Carolina, aims to preserve "that culture which has not been learned from books, but by word of mouth or by physical demonstration has been spread informally from father to son, from neighbor to neighbor, through generations of North Carolina history."

\section{Music and Art}

The American Musicological Society is publishing a new journal with articles and reviews of books on subjects in its field, as well as announcements and society reports. The Gesellschaft für Musikforschung, together with Landesinstitut für Musikforschung and Institut für Musikforschung have begun Die Musikforschung in Kassel, to publish critical and historical studies. From Stuttgart there comes Graphik, die Zeitschrift für Gebrauchsgraphik und $W$ erbung, a well illustrated journal on industrial and commercial art.

\section{Science}

Applied Scientific Research, a journal which began publication in 1947 but was not examined in time for inclusion in "New Periodicals of 1947 ," is included here because of its importance. It is published at The Hague under the auspices of the Central Organization for Applied Scientific Research of the Netherlands, the Royal Institute of Engineers of the Netherlands,
Section for Technical Scientific Research and the Netherlands Physical Society, Section for Applied Physics. It is in two sections, Section A, Mechanics, Heat, and Section B, Electrophysics, Acoustics, Optics. Other sections may be added in the future. It will publish, preferably in English, the results of new research. Naturwissenschaftliche Rundschau is an interesting new monthly from Stuttgart. A few of the subjects included in the first issue are food, nutrition, astronomy and oceanography. Physics Today, published by the American Institute of Physics, is intended to inform the physicist and the nonphysicist in nontechnical language of what is going on in the field of research in physics. Taiwania, from the Laboratory of Systematic Botany, National Taiwan University, is a journal of plant taxonomy and geobotany, devoted particularly to the floras of eastern Asia, Indo-Malaysia and the western Pacific. $W$ ald und $W$ ild, a new natural science magazine, popular in style, published in Würzburg, will be of interest to sportsmen and outdoorsmen. A scholarly publication, Zeitschrift für Angewandte Physik, publishes articles based on studies done in German research institutions.

\section{Engineering}

Zeitschrift für Elektrotechnik, Stuttgart, is devoted to electrical engineering, especially high voltage engineering.

\section{Physiology}

To meet the need of a specialized journal in the field of physiology, the American Physiological Society has begun Journal of Applied Physiology which will complement its older and more general American Journal of Physiology. The term "applied" as here used will connote human physiology, with particular emphasis on man in relation to his environment. 


\section{Psychology}

Personnel Psychology "has been founded to stimulate and report the application of psychological methods, understandings, techniques and findings to personnel problems." Papers are to be understandable, accurate and useful to personnel workers at all levels. A scholarly publication is The Quarterly Journal of Experimental Psychology. It hopes to foster the experimental approach to psychological problems and through publication of such studies to correlate the research done in universities, clinics, laboratories, and industry. Your Human Relations has for its object the study of ways of improving human contacts. Its articles and stories written in a popular style have as their characters leaders in business, industry, education, religion, science and other fields.

\section{Agriculture}

The science and art of grazing land management is being covered in Journal of Range Management published by the American Society of Range Management. Another new journal intended to be of international interest, is Plant and Soil, a journal of plant nutrition, plant chemistry, soil microbiology and soil borne plant dis- ease. It is issued at The Hague under the auspices of the Netherlands Society of Agricultural Science. Some articles are in English, some in French, and some in German.

\section{Law}

Two new law journals appeared, Journal of Legal Education published by the Association of American Law Schools, and edited by the Faculty of Law, Duke University, and Oklahoma Law Review published by the University of Oklahoma Press. Contributors to both publications are practicing lawyers and law school professors.

\section{Autographs}

The National Society of Autograph Collectors have inaugurated The Autograph Collectors' Journal with illustrated articles and society news.

\section{Microfilms and Microcards}

The Micro News and The Microcard Bulletin are intended to keep the public upto-date on the developments in, and regulations and equipment for, these new methods of publishing and copying.

\section{Periodicals}

American Musicological Society. Journal. American Musicological Society, I4 Beacon Street, Boston. no. 1 , April 1948, 3 nos. a year. $\$ 6.50$.

Applied Scientific Research, Section A-B. Martinus Nijhoff, The Hague. v.r, no.r, r947. Irregular. f.20 per section.

Archaeology. Archaeological Institute of America, Andover Hall, Cambridge 38 , Mass. v.r, no.r, March 1948. Quarterly. \$6.

Archives Ethnos. English Edition. Santa Fe r940 E., Buenos Aires, no. r, May 1948. Frequency not given. $\$ 2.50$.

A sian Horison. Asian Publications, Ltd., 34 Victoria St., London, S.W.r. v.r, no.r, Spring 1948. Quarterly. $15 \mathrm{~s}$.

Asir. Mercedes, Uruguay. no. I, March 1948. Io nos. a year. Price not given.

The Autograph Collectors' Journal. E. B. Long, Editor, 4043 N. Greenview Ave., Chicago r3. v.r, no.r, October 1948. Frequency not given. \$5.

China Economist. Millard Publishing Co., Inc., 160 Chung Cheng Road (Eastern) Shanghai (O). v.r, no. r, April 6, r948. Weekly. \$9.
Contemporary Issues. Contemporary Press, 67 Clarendon Road, London W.r. v.r, no.r, Summer 1948. Quarterly. \$r.6o.

Contrapunto. Cristo a Córdova No. 4, Caracas. no.r March 1948. Frequency not given. bs.2 per issue. Corps Diplomatique. I50 Avenue des Champs-Elysées, Paris. no.r, July r 948 . Monthly. \$9.

Eastern Review. Verlag Ferd. Kleinmayr, Klagenfurt. v.r, no.r, April r948. Quarterly. \$.80 per issue.

Économie Wallonne. Imp. G. Thone, Liége. no.r, August 1948. Frequency not given. Price not given.

Études Internationales. Librairie Encyclopédique, 7 Rue du Luxembourg, Brussels. v. I, no. I, January 1948. Quarterly. 210 frs. b.

Factotum. Box 6r2, Chapel Hill, N.C. no.r, May 1948. Quarterly. $35 \%$ per issue.

The Golden Goose. Cronos Editions, Box 3103 , University Station, Columbus 10, Ohio. no.r, Summer r 948 . 4 nos. a year. \$r.40.

Graphik. Graphiker Maiwald, Augustenstrasse 43 Stuttgart. no. $1 / 2,1948$. Bimonthly. Mk. 8 per issue. Italian Publishers' Monthly. Romolo Costa, Viale Regina Giovanna 22, Milan. no.r, January r948. Free. 
Journal of Applied Physiology. 2ror Constitution Ave., Washington 25. v.r, no.r, July 1948. Monthly. $\$ 7.50$ $\$ 8.50$ foreign.

Journal of Legal Education. Duke Station, Durham, N.C. v. I, no. I, Autumn I948, Ouarterly. Free?

Journal of Range Management. American Society of Range Management, Mt. Royal and Guilford Aves., Baltimore 2. v.r, no.r, October 1948. Quarterly. $\$ 3.00$.

Korean Review. Thomas Kang, 445 Quincy St., N.W., Washington. v.r, no.r, June 1948. Semiannual. \$r.

Le Livre. I 6 Boulevard St. Germain, Paris 6. no.r, May I948. ro nos. a year. $\$ 4$.

Lusitánia. R. Actor José Ricardo, 3, r/c, Lisbon. v. I, no. I, May 1948. Monthly. $180 \$ 00$.

The Micro News. National Microfilm Association, Io Lafayette Ave., Hingham, Mass. v.r, no.r, March 1948. Bimonthly. Price not given.

The Microcard Bulletin. The Microcard Foundation, Middletown, Conn. no.I, June 1948. Quarterly? Free?

Die Musikforschung. Bärenreiter-Verlag, Kassel. v,r, no. $1,1948.4$ nos, a year. Mk. 24.

Naturwissenschaftliche Rundschau. Wissenschaftliche Verlagsgesellschaft m.b.H., Stuttgart. v.r, no.r, July 1948. Monthly. Mk. 7.20.

Neurotica. The Neurotica Publishing Co., 44381/2 Olive St., St. Louis 8. v.1, no.1, Spring 1948. Quarterly. \$2.

The New Central European Observer. 35 Pond St., London, S.W.r. v.r., no.r, May 15, 1948. Biweekly. $\$ 4$.

North Carolina Folklore. The University of North Carolina, Box ro50, Chapel Hill. v.r, no.r, June 1948. Frequency not given. $\$ 2$.

Oklahoma Law Review. University of Oklahoma Press, Norman. v.r, no.r, May 1948. Quarterly. \$5.

Pakistan Horizon. Pakistan Institute of International Affairs, Fere Hall, Karachi, v. 1, no. I, March 1948. Frequency not given. Rs, 8 .

Personnel Psychology. I 727 Harvard St., N.W., Washington 9. v. $\mathrm{x}$, no.r, Spring 1948. Quarterly \$6. Foreign $\$ 7$.

Physics Today. American Institute of Physics, 57 East 55 th St., New York 22. v.I, no.r, May 1948. Monthly'\$4.
Plant and Soil. Martinus Nijhoff, The Hague. v.r, no.1, January 1948. 4 nos. a year. Guilders 20. Poesi. Wahlström \& Widstrand, Regeringsgatan 83 Stockholm. no. I, I948. 4 nos. a year. Free to members of Lyriksamfundet.

Prisma. P. A. Norstedt \& Söners Förlag, Stockholm. v. $\mathrm{x}$, no. $\mathrm{I}, 1948.6$ nos. a year. kr. 14.

The Quarterly Journal of Experimental Psychology. W. Heffer \& Sons, Ltd., Cambridge, Eng. v.r, pt.r, April 1948. \& I ro s.

Revista de Economia. Eurico Colares Vieira, Apartado no. $4_{42}$, Lisbon. v.1, no.r, March 1948. Quarterly, $55 \$ 00$.

La Revue du Chef d'Entreprise. Editions Ocia, 3 Rue Cardinal Mercier, Paris, no.r, 1948. Monthly. 600 frs.

Der Städtetag. W. Kohlhammer Verlag, Stuttgart, v.r, no. $1 / 2$, July/August 1948. Monthly. Price not given. The Swan of Avon. The Melander Shakespeare Society, Santa Barbara, Calif. v.r, no.r, March 30 , 1948. Quarterly. Price not given.

Taiwania, Laboratory of Systematic Botany, Dept. of Botany, College of Science, National Taiwan University, Taipei, Taiwan, China. v.r, no.r, May 1948 . Irregular. $\$ 7$.

Wald und Wild. Lothar Sauer-Morhard Verlag, Würz berg. v. I, no. $1 / 2$, September 15, 1948. Monthly. Mk. 12 .

World Politics. Yale Institute of International Studies, 202 Hall of Graduate Studies, Yale University, New Haven. v.r, no.r, October 1948. Quarterly. $\$ 5$.

World Trade Review. American Register World Trade Review, 170 Broadway, New York 7. v.r, no. I, February 1948. Monthly. \$1,50.

Your Human Relations. Public Relations, Inc., 522 5th Ave., New York, 18. v.r, no.r, January 1948. Monthly $\$ 5$. Foreign' $\$ 15$.

Zeitschrift fiir Angewandte Physik. Springer-Verlag, Heidelberg. v.r, no.r, January 1948. Monthly. Mk. 7.50 ,

Zeitschrift für Elektrotechnik. Ferdinand Enke, Stuttgart. v.r, no.r, April 1948. Frequency not given. Price not given.

Zeitschrift fïr Religions. und Geistesgeschichte. E1wert-Gräfe und Unzer Verlag, Marburg. v.r, no.r, r948. Quarterly. Mk. 6 per issue.

\section{The College Librarian in the Academic Community}

\section{(Continued from page 134)}

teaching staff, and they should be accorded the same privileges as all teaching staff with respect to tenure, sabbaticals, salary increments, and retirement. They should receive generous vacation allowances and special arrangements should be made, when possible, to permit them to pursue graduate studies. Library staff members should be invited to participate in those faculty and general college committees on which they are qualified to make a contribution. As head of an important instructional department the chief librarian should enjoy equal status with other instructional department heads. In those instances where the library is large and its resources and services warrant, he should be given equal status with deans and other high administrative officers. These suggestions may shock some college administrators and even a few college librarians. They are submitted in friendly and constructive spirit as-logical conclusions to be drawn from acceptance of the position that college libraries are important educational agencies and their professional staffs are clearly instructional personnel. Given equal status with other instructional personnel the college library staffs can be expected to participate actively and effectively in the affairs of the college and to contribute in high degree toward the attainment of its aims and purposes. 